\title{
Current Discussions in the German Integration Debate
}

The Culturalist Vision vs. Social Equity?

O. Can Ünver

\section{(2) OpenEdition \\ Journals}

Electronic version

URL: https://journals.openedition.org/remi/3241

DOI: $10.4000 /$ remi.3241

ISSN: $1777-5418$

\section{Publisher}

Université de Poitiers

\section{Printed version}

Date of publication: 31 December 2006

Number of pages: $23-38$

ISBN: 978-2-911627-43-9

ISSN: 0765-0752

\section{Electronic reference}

O. Can Ünver, "Current Discussions in the German Integration Debate", Revue européenne des

migrations internationales [Online], vol. 22 - $\mathrm{n}^{\circ} 3$ | 2006, Online since 31 December 2009, connection on

14 April 2022. URL: http://journals.openedition.org/remi/3241 ; DOI: https://doi.org/10.4000/remi. 3241

This text was automatically generated on 14 April 2022

(c) Université de Poitiers 


\title{
Current Discussions in the German Integration Debate
}

The Culturalist Vision vs. Social Equity?

\author{
O. Can Ünver
}

1 Contemporary discussions with regard to Turkish migrants integration in Germany are heavily penetrated by popular culturalist ideas, signifying methods through which the Turks should be adapted to the society, to a society that still discusses identity nuisance even in the 45th year of Turkish labour migration. The content of this kind of discussion is so pervasive that many observers find it disgusting and in some way depressive. As a matter of fact, the thriving conquest of culturalist efforts in this field seems to be the basis for those, who claimed all through the years of migration history to the main host country for Turks, that a successful integration would suggest more cultural amalgamation than a certain degree of equity in the education, labour market and earnings between the migrants and the natives. Despite the legal and political efforts of the host country's governments since the very beginning, the relative success to pave the way to an improved atmosphere for the comprehension of integrating Turkish migrants need to be scrutinized under the premise of a new perception of social equity in the welfare state and trans-national developments.

2 The culturalist approach hinders a logical and a free-from-emotions-debate, which could demonstrate the appropriate methods of a factual integration into the host society. Main centre of attention is generally put on religious and national identities. The issues such as professional and social mobility are extensively being ignored and the alleged cultural distinctiveness of the migrantplays the most significant part in this debate. The paradigm of parallel society dominates the migration discussions through the media to the political decision making in Germany. To this end, publications by some authors of Turkish origin with a trendy upshot prejudiced the debate blaming a poor defined Turkish culture, especially the religious belief, as the handicap for integration (Ateş, 2005; Kelek, 2005 and 2006). They generally claim that the majority of the host society shows in fact a higher quality of willingness to integrate those with their different and 
outlandish culture. Accordingly, the reluctance and self-isolation of the groups with migration background make the integration efforts of the host society unfeasible.

The next concern of the integration discussants - not only in Germany, but in the whole Western hemisphere - takes place on a basis of ambivalence: public security appears to be one of the key issues, both in the policy making process and in the field of migration research (Angenendt and Cooper, 2006). The comprehensible public concern of security as regards to migrant population was, on the other hand, in some way embellished, so that the potential of adaptability among migrants, especially second and following generations, could suffer from severe damage, at least in their minds. The banlieue riots in France in November 2005 caused for alarm in other parts of Europe, also in Germany, albeit the local conditions in different immigration countries are hardly to compare with the factual conditions and the background of unrest in France. The justified security matters should in no way influence the willingness of migrant individuals, who should feel themselves as rightful members of the host society. To comply with this principle is the responsibility of the policy makers. On the other hand, the research in the field of migration should put the emphasis on the justified wishes of the migrant individuals to be accepted by the entire community to which they have to adapt themselves, in a society of social equilibrium between foreigners and natives. A stronger accentuated culture of acceptance seems to be indispensable for social peace in contemporary Germany, hence a new understanding of reciprocal recognition with a higher priority for individuals' social mobility with migration background. The medially overemphasized intercultural affairs and perceptions of ethnical characteristics with all its peculiarities may then simply play a secondary role in the migration debate. Migration became in our world of global conflicts a rather fashionable highly politicised concern with a relatively popular emphasis on ethno-culturalism, both in migration research (Bommes and Moravska, 2005) and predominantly in policy making. To avoid it to be the most pivotal issue and a security risk for the future prospects of the host countries' society as well as for the migrant individuals, the main concern for a new understanding of integration management through a trans-national approach (Faist, 2000) appears to be the duty of our time.

5 In this article, the endeavour is an outlined reflection of the inadequacies of the current integration paradigm in Germany from the Turkish insider's point of view and to put forward a comprehensive and all-embracing approach towards a trans-national basis to overcome present and forthcoming clashesamongcultures. The current educational, economic and social situation of the Turks in Germany depicted in this article refers to a great extent not to their reluctance to integration, but to lots of shortcomings and of measures to be taken by all partners of migration/integrationprocess.

\section{Turks of Germany: the picture of a settling minority}

6 Turkey's experience of emigration has a relative short history. The ever first emigration of Turkish guest workers toEurope took place in the second half of the 50's through private channels (Abadan-Unat, 2005: $62 \mathrm{ff}$.). The beginning of the institutional recruitment of workers from Turkey within the guest worker system was the bilateral agreement between the Republic of Turkey and the Federal Republic of Germany in October 1961. Other countries, Austria, Belgium, Holland, Switzerland, France, Sweden 
and Denmark followed this path of importing workforce from Turkey, so that by November 1973 nearly 1,5 million Turks, mainly male single industrial workers, were incorporated into the then European Fordist mass production (Abadan-Unat, 2005: 68; TC Çalışma ve Sosyal Güvenlik Bakanlığı Dış İlişkiler ve Yurtdışı İş̧i Hizmetleri Genel Müdürlüğü, 2002: 23-27). In November 1973, further recruitment was stopped by the Government of the Federal Republic of Germany, as a reaction to Oil Crisis and to mitigate the emerging recession of the welfare state. The guest worker system, which was originally anticipated to be restrictive and designed with the principle of rotation of migrant workers after certain working periods in the host country, with a view to obviate additional social costs, believed to be inappropriate by the policy makers (Castles and Miller, 1998: 67 ff.; Schierup, Hansen and Castles, 2006: 146). The foreign work force, which was growing by new recruitments - conceivably as an exigency of the employers - was blamed for exacerbating the employment market. Full employment and due social cohesion began to rattle in the welfare systems of post-war Europe in the first half of the 70s (Castles and Miller, 1998: 78; Schierup, Hansen and Castles, 2006: $139 \mathrm{ff}$.). A new era of declining mass industrial production and a growing services sector, segregation both in social rights and in the vocational domain with an overcoming neo-liberal workfare ideology (Schierup, Gray) disfavouring welfare state achievement of the post war epoch began its reign. The recruitment to Germany was stopped and the returns to Turkey slowed down (Abadan-Unat, 2005: 73).

7 Turkish immigrants' choice of the first generation, whose members were recruited within the framework of the above said bilateral agreement, seemed to be the prolongation of their stay as long as possible and to overcome the parochial legal requirements in the legislation of the Federal Republic that never accepted an immigration of foreigners with a view to permanent settlement. The scheme of a longer stay premised the unification of the family members on the territory of the receiving country, which precipitated consequently apprehensive public debates, calling for more legal and administrative restrictions, mostly from the right-wing politics. The prevalent line in the discussions was that Germany had never been an immigration country (Schierup, Hansen and Castles, 2006: 144-151). Though, the Foreigners' Act of 1965 was the eve of a development which should boost the elaboration of the new legal/political framework of migration/integration problematic in Germany. The following decades up to the millennium served as a stage for further mitigation of the debate, with ups and downs, reticently implying that Germany turned out to be an immigration country and finally accepting this fact, which was accentuated in the recent legislation - notwithstanding some positions of criticism still exist (Keskin, 2005; Schönwälder, 2004; Oberndörfer, 2005; Schierup, Hansen and Castles, 2006). The Citizenship Act of 1999 (came into force on 1.1.2000) and the Immigration Act of 2004 (came into force on 1.1.2005) give us certain clues in an ongoing process. The Citizenship Act was accepting for the first time that ius solis in addition to ius sanguinis for the German citizenship. This novelty was assessed as a modern step forward, though the same Act prohibited dual citizenship to a great extent, because the social democratic-green coalition was forced to be compliant to the Christian democratic opposition, which organized a plebiscite against dual citizenship in Hesse. Despite criticisms with regard to shortcomings in the new legislative framework, Germany was indeed trying to transform her longstanding paradigm of being a non-immigration country that was already outdated decades ago (Schönwälder, 2005). 
8 The most vulnerable group, which became the scapegoat in the course of the whole debate on migration and integration, was the Turks. This group of early guest workers and their descendants were broadly recognized, both by the public opinion and the politics, as a homogeneous divergent group in a firm culturalist manner. Hence, a ubiquitous discordant group of foreigners was in the country, incapable of being incorporated into the mainstream society, and raised a parallel society that could be threatening to the integrity of German way of life. This common prejudice, which has its roots in the history.

9 At this point, it seems to be appropriate to scan and reflect the present situation of the Turkish community in Germany. The population of the citizens of the Republic of Turkey by the end of 2005 was 1.764 .000 (TC Berlin Büyükelçiliği Çalışma ve Sosyal Güvenlik Müşavirliği, 2006). With ca. 700.000 German citizens of Turkish origin, a total number of more than 2,5 million Turks, both foreign and Turkish born, live in Germany. Turks build up the largest immigrant group in the country, disseminated mostly in old Länder and Berlin. The largest Turkish community in a single land is in Nordrhine Westphalia with a total population of nearly 900.000 people. Berlin is the metropole with the higher concentration of Turks in a single city: according to some estimation - beyond official data - the contemporary Turkish population in Berlin sums up to nearly 120.000 (TC Berlin Büyükelçiliği Çalışma ve Sosyal Güvenlik Müşavirliği, 2006). The recent demographic development reveals the present structure of the Turkish community in Germany: nearly 850.000 Turks are below the age of 29 (TC Berlin Büyükelçiliği Çalışma ve Sosyal Güvenlik Müşavirliği, 2006). The number of elderly Turks above the age of 65 is 100.000 . According to data collected by the Turkish Embassy in Berlin, more than 500.000 school children and nearly 30.000 university students of Turkish origin were matriculated in the educational institutions. The current state of affairs in education of Turkish migrants in Germany is but more than alarming. According to PISA 2003 of OECD (Programme for International Student Assessment), the school performance among Turkish second generation migrant children is in comparison to native children is alarming. The low attendance rate to kindergarten due to somehow unaware or uninformed parents, but also lack of opportunities to offer pre-school education to every child below six years of age, could outline some aspects of the German education predicament with regard to migrant children. The German Sonderschule, the school for children with learning handicaps, serves mainly to foreign children. If not enrolled to these highly unprivileged schools, most of the Turkish students will than attend lower levels of the secondary school. Only $19 \%$ of foreign students are able to attend the Gymnasium; the Turkish rate there is even lower. The deteriorated situation of these children with migration background seems to be a consequence of the German trajectory school system with a relative early ramification that has stronger impacts on the migrant families. (PISA, 2003) The attendance rate to Hauptschule, the school for preparation to vocational training, is dramatically higher than the German students' rate of attendance: 50 to 21\% (Schierup, Hansen and Castles, 2006: 159). Less than 10\% of Turkish students can reach Abitur (certificate necessary for higher education admission). The rate among German students is approximately 26\% (Schierup, Hansen and Castles, 2006: 159). The participation at vocational training rate among those with migration background is in addition lower than their German students of the same age (15 or 16): 68\% of young Germans were 1999 in apprenticeship, whilst the young foreigners reached a rate of only 39\% (Schierup, Hansen and Castles, 2006: 160). The majority of young Turks is 
enrolled for vocational training with lower qualification professions such as mechanics, hairdressers or retail clerks and will not have the opportunity of promotion after training.

10 The chronic unemployment affected by internal and global factors in the national economy has deeper impacts on the relative vulnerable group of workers, namely migrants with low vocational qualifications. In comparison to overall unemployment with an average rate of $10 \%$ at present, the unemployment rate among Turks in Germany was an alarming $32.1 \%$ by August 2005. Approximately, 200.000 Turks are registered as jobless by the Federal Agency of Employment in the first eve of 2006 (TC Berlin Büyükelçiliği Çalışma ve Sosyal Güvenlik Müşavirliği, 2006). In Berlin, unemployment rate even reached $48 \%$, ostensibly an attribute to the post-Fordist and deregulated employment market, outsourcing of plants to low-cost countries and an evident loss of industrial work places for low and semi-qualified work force. The overwhelming majority of the Turkish unemployed, who participated before redundancy at the declining mass production that required not more than semiqualified workforce, belong to the semi- or unskilled blue-collared workers in the age group of 45-60. The redundancy among unqualified younger workers must be even more dilettante. The welfare system in post-war Germany with a long tradition since the $19^{\text {th }}$. Century, and a profound structure to comply with the requirements of the fullemployment era, has currently severe troubles to prevail over. Chronic unemployment, which indicates a declining tendency in the last three months of 2006, probably as an early outcome of the recent employment market reforms, containing incentives within the framework of present active employment policies, seems to be the key dilemma for the social cohesion in Germany. As a matter of fact, the most vulnerable group in the society, unemployed with migration (i.e. Turkish) background, becomes the most affected by these circumstances.

11 Chronic unemployment was one of the incentives for the redundant Turks among who were several unqualified former industry workers, looking for subsistence opportunities and commence as small business entrepreneurs. So, by the end of 2005 some 60.000 "Turkish" enterprises, supposedly employing more than 300.000 workers, among them Turks and other nationalities, were recorded by the Chambers of Commerce of the Federal Republic. (TC Berlin Büyükelçiliği Çalışma ve Sosyal Güvenlik Müşavirliği, 2006). Among these enterprises, a growing number of companies in the services and trade sectors, with an extensive profit level in different parts of the Federal Republic, contribute definitely to economic life of the country. Notwithstanding the fact that this kind of entrepreneurship mainly springs off an exacerbated employment market, it is of vantage for the national economy and a subsistence opportunity for investing/working individuals, maybe even more beneficial for their children, who will grow up under better conditions and will presumably have a better education and professional opportunities than their ancestors. This development is, on the other hand, criticised by many observers, who deal with integration issues and Turks are accused of forming a hostile parallel society by their ethnic niches. This idea is highly related to ethno-racial discriminatory evidence in Germany and racial crime in different parts of the Republic, cannot be challenged totally in spite of effective government efforts (Deutscher Bundestag, 2006)1.

The Turkish community, albeit it does not show any characteristics of social homogeneity as a whole, is consisted of individuals, whose majority is determined 
conspicuously to stay in Germany. The common denominator among the young Turks is seemingly their determination to be a part of this country (Kaya, 2005). The developments hitherto demonstrate certain tangible clues within the Turkish community, especially among younger generations, that in spite of contemporary inadequacies with respect to their present and future perspectives, the inclination to be equal citizens of the society is remarkable, i.e., they are resolute to participate at social, economic and political life (Kaya, 2005). Active political participation at communal, regional and federal levels is an emergent indication of a substantial incorporation into the mainstream society. There is convincing empirical evidence that they consider themselves as part of the host society, although, on the other hand, many signals are still in existence, implying definite moments of frustration within the Turkish group (Zaptçığlu, 2006; Ünver, 2006). They describe their identity usually as Germany Turks, who can be loyal to both countries; hence, maybe a new and exciting transnational identity is emerging, which could redesign future policies in a transnational world with blurred border lines. (Kaya, 2005; Faist, 2004). As long as buoyant incorporation policies are elaborated and prevalent social exclusion practices are hindered through affirmative action, younger generations could be anticipating a positive vision for their own future in Germany. The prerequisite for the creation of such a fundament for social inclusion gives the impression to be at least the mitigation of the current culturalist debate and substitute it by novel aspects of social equilibrium in the society. What these aspects as a matter of social cohesion in a "declining welfare state" (Schierup, Hansen and Castles, 2006) could be, is discussed further below.

\section{Disliked guests, who are incapable of being integrated?}

The integration debate in Germany, as already mentioned above, is strongly influenced by the culturalistic views, which pervade thoroughly the country's political culture. So, the current discussion is being carried out mainly with aspects of alleged religious distinctiveness and thus incapability of social and cultural adaptation to the mainstream society. This path implies definite determinants for the incorporation policies with a strong pressure on the migrant community to contemplate its own ethnical and cultural identity. The right-wing populist and racial ideas, having also latent impact on the civic culture of the society as daily reflected in the media as regards to matters concerning Turks in Germany, could precipitate a substantial reluctance within the Turkish community for corporate living. In the following, the general depressing - and in the literal sense of the term at least frustrating - current paradigm on Turks in Germany will be evaluated.

The political culture with respect to Turks and Turkish affairs in Germany - as in other countries of Western Europe - is apparently deeply predisposed by historical tradition of religious, military and political conflicts (Ünver, 2006). The reconciliation, which was an outcome of reciprocal win-win situation since the establishment of the Republic of Turkey and mainly after the World War II until the end of the Cold War in an environment of regional and global pressures and hostilities, came emotionally to an end, despite the essential step taken by Europeans, namely the recognition of a possible full membership of Turkey in EU and other bilateral connections in different domains: political, economic, cultural and social rapprochement within the framework of Turkey-EU context. These unyielding formal connections between Turkey and most of 
the EU-member countries are indeed irreversible. On the top of the list of Turkey's main economic partners are European countries with Germany on the first rank. The existence of a strong Turkish community with nearly 2.6 million members contributes to the above mentioned inextricability: though not each time publicly asserted, migrants' issues have developed one of the essential bilateral ties in the foreign policy settings of both partner states, not to mention other areas of a decades-lasting mutual co-operation. Migration to Germany was and is a perceptible factor in the overall relations between Turkey and Germany. With the changing political environment in the aftermath of the Cold War, migrants of Turkish origin became a highly politicised and even dramatised issue in the public debate, which shows since than a persistent rising trend. The notorious new culturalist ideology of globalisation, the clash of civilizations, provided the paradigmatic fundamentals to the new emotional paths of argumentation, which indeed could refer irrationally to frozen prejudices from the past. Islam became the issue; principally after $9 / 11$ terrorist attacks and a new type of Islam phobia was refurnished with repeated terror attacks to different European metropoles such as Madrid, Istanbul and London. Although, not even a single Turkish individual from the migrant communities in all European former receiving countries was not entangled into any terrorist activity, the nearest scapegoats were then for most of the Europeans the Moslem Turks, their neighbours, their colleagues and their school mates. The tragic loss of the film director van Gogh in Holland, whose murderer was a young Netherlands citizen of Moroccan background, hence a Moslem, who in fact grew up there, constrained the emotions throughout Europe. Although, that tragic event shouldn't be evocative for the real situation of the Moslem Turks in Germany, struggles to create analogies were registered, even by the serious print media.

Another point of ambivalence within the context of Turkish discussions in Germany and elsewhere in Europe happened to be the Turkish objective to join the EU. An associated member since 1964, Turkey delivered her formal application already in 1987 in Brussels, which was comprehended as an expected consequence within the process of her association with the European supranational body. The political voices in particular states in Europe, strongly opposing a full membership of the Moslem Turkey although secular - contributed -consciously or unconsciously - to an emerging antiTurkish motivation, both in the public opinion and in the policy making. Germany played a primary role in conducting European Turkish policies in the last 10-15 years. Both the confirmatory action for Turkish candidacy launched by the former Social Democrat Chancellor Gerhard Schröder, but the previous politics of disagreement during the long lasting Government of Christian Democrat Chancellor Helmut Kohl were policy outputs of the Federal Republic Germany, which affected European policies simultaneously. As a matter of fact and as a consequence of all these - still progressing - incidents, Turkish distinctiveness was confirmed not only in the minds of elites of the receiving country. Culture, religious faith and national identity became the focal notions in discussing Turkish matters (Wehler, 2004; Keskin, 2005: 243 ff.).

So, the Turkish paradigm was perfect: Turkey did not belong to Europe, owing to her cultural otherness and geographicallocation, and the Turks in the country, former guestworkers and their settled descendents, an ostensibly homogeneous Moslem group, which is therefore incapable of incorporation, and simultaneously forming a threat to the economically, socially and politically consistent mainstream society. The corporate institutional and political struggle of the host country should now be the deterrence of 
this rigorous threat, which is perceived actually as a cultural one and not a social or economic discordance in the whole society!

There might in fact be no society in the world, which is totally free of definite prejudices as regards friendly or hostile nations or interior groups surrounding it, but prejudiced approaches may make efforts of reconciliation between individuals and groups unworkable, so that allegedly divergent migrant groups could form easily an introverted behaviour or different kinds of in-between-attitudes, which harm incorporation efforts, if there are any. This precipitates factually the formation of a social excludedgroup with rather indefinite group characteristics, except religious faith, and not the so-called parallel society, signifying more or less a societal formation to resist and oppose the customary merits of the society and even the legal framework of the state. The formation of the so-called parallel society should be perceived consequently as an undeclared opposition to the achievements of the mainstream society. If the actual circumstances hereto were existent, this issue need to be scrutinized closer, considering different political, sociological, economic and anthropological aspects of the issue. It could only be set with definite empirical evidence. The picture concerning the Turks of Europe doesn't illustrate any of the aspects of such empirical evidence. On the contrary, the vivid substantial desire for incorporation of the large masses of integrated Turks in different countries, supplies us with definite indications of inadequacy of such reprimand within the elites, who are the prevalent opinion leaders of the society.

The opinion leaders, who represent the above mentioned culturalist line, accuse the migrants from Turkey, simply because of their Islamic faith and national identity, for not being able to be integrated into the society. Such cultural essentialism is supported by individual so-called customary murders and widespread gender problems, which usually are substantiated by religious or group specific culture, albeit the real reasons should be looked for at the unchanged feudal family structures. ${ }^{2}$ The by the German media recently popularized author, Necla Kelek, criticises the cultural customs and religious faith of the Turks in Germany, and from her point of interpretation, she accuses nearly the whole community, implying significant clues to a racist location of the problem (Kelek, 2005; 2006). So, the popular culture of the Turks becomes the essential threat: hence, it should be relativized by significant assimilation methods, such as aggravating the admission to citizenship, prohibiting the usage of the mother tongue at the nursery schools and denying the trans-cultural ties to the country of origin. These ideas are located currently in increased interactions in the newly designed policies and cause for anxiety among the Turkish community with migration background - just to use the popular notion -, although the vast majority of the Turks are born in Germany. They already belong to this society and essentially are being more predisposed by the prevalent state of affairs in their environment, and their social benevolence to design their position within the community and the mainstream society depends upon the patterns of their social strata.

19 So, the persistence to assert developments with a perspective of cultural essentialism is not conducive to a politically desirable corporate living in the society. This conflictoriented approach requests furthermore the acceptance of a German Leitkultur (guiding culture), a notion, which itself cannot be defined. Oberndörfer (2005) argues there exist no German Leitkultur, which should give lifelong guidance to the culturally distinctive foreigners. In fact, how could be possible to define the guiding culture of a democratic 
pluralistic society? How could we convince human beings in such a society to adjust themselves to customary rules of the native population or how could the traditional attitudes that they have taken over from their ancestors, be abandoned? What kind of incentives or predicaments should be used to achieve the acceptance of the Leitkultur? Could we than speak of a democratic society, if members of this society are urged to give up their national identities or religious faiths? Is the essential Leitkultur of a democratic society not the adherence to legal obligations, to democratic rules and compliance with fundamental and human rights? Such questions should surely be answered before seriously suggesting a social and even culturally heterogeneous group to adopt a certain Leitkultur, a highly notorious notion, which has different amorphous definitions, and which causes additional nuisance to an issue that nonetheless turned out to be complicated. The principle problem in the whole seems to be the lack of adequate approaches, recognizing not only the cultural dispute, but also, with even greater attention, the economic and social circumstances that influence every member of the society irrespective of their cultural, religious or ethnic identity, and especially reconsidering the cultural supremacy and segregation paradigms with respect to social matching.

\section{Policy options and future prospects}

At present, Turks in Germany undergo a deep social change. Elder generation leaves the active employment life and begins a mostly trans-national living as pension beneficiaries. The younger generations, who do not reasonably share common worries and prospects with their predecessors, expect effective corporate action to boost policy accomplishments with concrete results. The basic problems are education and inclusion into labour market. The society's expectancy, to eradicate supposed integration problems through well designed policies, is improving and the related discussion is reaching new dimensions. This new discussion contains predominantly aspects of the above criticised culturalistic and conflict-oriented ideas. There is indeed a conflict situation with regard to foreign population in Germany: The debate on the cultural distinctiveness provides a fundament to racial-popular activists, who dramatically problematises the very existence of the foreign population - mainly Turks -, and acquire sympathy not alone from their own relative small adherents, but also from broader layers, whose members suffer from redundancy and an emerging poverty in the German society. Economically weakened stakeholders of the welfare system are desperately opposing the foreigners, who indeed are born in Germany, and as equal affected members of the society, carry the burdens of neo-liberal/global workfares policies (Schierup, Hansen and Castles, 2006: 161-162).

21 The profound crisis of the welfare state urged the policy makers to undertake measures that should be conducive to more employment and therefore being able to break the Circulus vitiosus, and current financing problems of the welfare system, caused by chronic unemployment as well as curtailment of the increased state subventions that were indispensable for the maintenance of the social security system. These measures, designed within the context of Lissabon Strategy, as part of the European Social Model, and among which vocational training incentives and active employment policies are considered to be the accurate means to prevail over the current difficulties, turned out to be at least medium ranged instruments. The permanent decrease of work places due 
to neo-liberal workfare ideology and global economic needs - outsourcing to low socialcost countries - interrupt or postpone the anticipated success from the applied policies, so that chronic unemployment continues to be the problem cited on top of the social agenda (Gray, 2004). Rapid structural changes in the working life - emerging of an enlarged service sector to the disadvantage of production industry and growing demand for highly skilled workers - contribute to the ambivalence of the described situation. Under these circumstances, the most vulnerable among the working or redundant groups of the society is obviously the unskilled workers with migration background of different ages, who either never participated at employment market or previously took part as unskilled or semi-skilled workers at the industrial mass production. The cultural essentialist view ignores the fact that the success of incorporation mainly depends upon subsistence through decent work - to comply with the notion used by ILO - and not necessarily forced cultural homogenization, which is not the major question in a democratic society, in which cultural diversification cannot be disqualified as a societal threat.

Appropriate options to realize a basis to evince equal opportunities for all members of the society should be the duty of the policy makers under the above mentioned circumstances of declining welfare system. The policies to integrate susceptible groups into the employment market should contain preferences of incentives that could be conducive to them. The basis for such policies should be the principles of equal treatment with regard to education, vocational training and other measures in all areas of social life. The cultural diversity should in the literal sense of the word not affect these policies.

In the nation states, equal rights can only be granted to citizens. The actual debate on citizenship in the age of global rapprochement, which put certain constitutes of the nation state in question, cannot be scrutinized at this point in depth. On the other hand, regardless of the fact that the majority of the migrant residents in a nation-state like Germany, which has at the same time obligations to a supranational body, are not citizens, they deserve equal treatment. The notion of denizen as first used by T. Hammar (Hammar, 1990; Soysal, 1994) could be supportive to grant equal rights to non-citizens. Some observers retain that the modern nation-state's ethno-centric influence is slowly dissolving (Glick-Schiller, Basch and Blanc-Szanton, 1997). Supranational binds and emerging trans-national spaces seem to be the future dominant factors. A new and more liberal European creed, as discussed by Schierup, Hansen and Castles, could form the future framework for migrant individuals and groups (Schierup, Hansen and Castles, 2006: 247-271). But currently, T.H. Marshall's social citizenship could be maintained as a valid notion; a real option prevailing solid ways to ameliorate cohesion in the society. (Marshall, 2006) The futility of the cultural essentialist views will than be better comprehended, if the problematical individuals are granted equal opportunities and rights to develop their own capabilities into an incorporated labour market: basis education and training good command of the native language and professional skills are the fundamentals on the way to equal treatment and incorporation. A formal citizenship solely can nevertheless be a magic solution for incorporation in a nationstate, which, despite formal acceptance of cultural plurality, still tolerates influences of cultural essentialist views and reflect them in its incorporation policies. A strong emphasis on cultural diversity as an obstacle to integration can than easily, in most 
cases under unconscious but benevolent glimpses of all participating partners of the process, lead into racial discrimination.

Another optional approach for a comprehensive policy of incorporation could be the recognition of the reality of new trans-national social spaces between Turkey and Germany, which Thomas Faist has thoroughly analyzed (Faist, 2000). The Turks of Germany, including their younger generations, prefer obviously to adhere to their cultural and national roots in Turkey. This preference should not signify any denial of incorporation into or co-habitation with the mainstream society. In fact, there are growing connections and multi-loyalties in the individual living patterns that could likely be evaluated as future prospects, in bilateral state relations as well as civic interactions with probably blurred future borders. This improvement does not necessarily promote the total disqualification of the nation-state authority. On the contrary, such trans-national connections could be better empowered under the auspices of the nation-state. To this end, necessary state sponsored structures will serve to enhance an environment of governance and reconciliation between states, communities and non-governmental bodies.

\section{Conclusion: needs of problem managment with a trans-national approach}

Current migrant's discussion in Germany reveals fundamental features of cultural essentialism. The contents and the rhetoric of the discussion are contaminated by precarious paradigmatic and normative observations, which have powerful controversial features on the one hand, and obstacles for a cohesive society on the other. For the advocates of this paradigm, Moslem Turks in Germany became the scapegoats for all systemic social and economic deficiencies. Culturalist views dominate the scene and the articulation of adequate measures to overcome the present inconveniences is being ignored. The solutions are principally sought within the assimilationist domain, insisting latently on a full cultural incorporation into a society, which cannot be defined by significant primordial cultural characteristics. The culturally distinctive Turks are believed to have formed a homogeneous group, and this group should be integrated into another allegedly homogeneous group, into the mainstream German society. According to this approach, all social hierarchies and the features of a highly segmented society are being ignored; social class arguments in concert with racial discriminations are being denied. This approach would never render a debatable initiative to discuss these highly controversial matters, whilst social equilibrium cannot still be achieved. The emergence of social questions had hardly anything to do with the cultural faith or ethnic identity of the Turks in Germany. The reasons should be sought in fact, as mentioned above, within the context of neoliberal/global achievements of the last twenty years in the Western hemisphere.

Another option to challenge the cultural essentialist approach in search of appropriate means for incorporation could be the recognition and deployment of newly emerging trans-national social spaces, accepting dual or more identities and generate conducive efforts to make them steadfast. This could possibly open new opportunities for the inner society reconciliation and inter-state relations, by which new types of partnerships to govern common migration and diversification management could be evoked. Social equity approach will than challenge the emphasized otherness in the 
society, hence dialog between equal partners could be fostered, and finally social reconciliation could prove to be achievable.

\section{BIBLIOGRAPHY}

ABADAN-UNAT Nermin (2005) Migration ohne Ende, Berlin, Parabolis, 424 p.

ANGENENDT Steffen and COOPER Belinda (2006) Zuwanderung in Zeiten des Terrors. Hilft erfogreiche Integration gegen die islamistische Bedrohung? Internationale Politik, Nr.3 März 2006, pp.6-14.

ATEş Seyran (2005) Große Reise ins Feuer. Die Geschichte eine deutschen Türkin, Berlin, Rowohlt, 251 p.

BOMMES Michael and MORAWSKA Ewa Eds. (2005) International Migration Research. Constructions, Omissions and the Promises of Interdisciplinarity, Cornwall, Ashgate, $289 \mathrm{p}$.

CASTLES Stephen and MILLER Mark J. (1998) The Age of Migration. International Population Movements in the Modern World, 2nd Edition, London, MacMillan Press, 336 p.

DEUTSCHER BUNDESTAG (2006), Antwort der Bundesregierung auf die Kleine Anfrage der Abgeordneten Petra Paul, Ulla Jelpke, Jan Korte und der Fraktion DIE LINKE - Drucksache 16/1950 - Ausländerfeindliche und rechtsextremistische Ausschreitungen in der Bundesrepublik Deutschland im Mai 2006, Drucksache 16/2195.

FAIST Thomas (2004) The Border-Crossing Expansion of Social Space: Concepts, Questions and Topics, in Thomas Faist and Eyüp Özveren Eds., Transnational Social Spaces. Agents, Networks and Institutions, Gateshead, Ashgate, pp. 1-34.

FAIST Thomas (2000) The Volume and Dynamics of International Migration and Transnational Social Spaces, Oxford, Oxford University Press, $380 \mathrm{p}$.

GLICK-SCHILLER Nina, BASCH Linda and BLANC-SZANTON Cristina (1997) Transnationalismus: Ein neuer analytischer Rahmenzum Verständnis von Migration, in Heinz Kleger (Hg.), Transnationale Staatsbürgerschaft, Frankfurt/New York, Campus, pp. 81-107.

GREY Anne (2004) Unsocial Europe. Social Protection or Flexiploitation? London-Ann Arbor, Pluto Press, 240 p.

HAMMAR Thomas (1990) Democracy and the Nation-State: Aliens, Denizens and Citizens in a World of International Migration, Aldershot, Avebury.

KAYA Ayhan and KENTEL Ferhat (2005) Euro-Türkler. Türkiye ile Avrupa Birli i Arasında Köprü mü Engel mi ?, İstanbul, İstanbul Bilgi Üniversitesi Yayınları, 223 p.

KELEK Necla (2006) Die verlorenen Söhne. Plädoyer für die Befreiung des türkisch-muslimischen Mannes, Köln Kiepenheuer \& Witsch, 211 p.

KELEK Necla (2005), Die fremde Braut. Ein Bericht aus dem Inneren des türkischen Lebens in Deutschland, Köln, Kiepenheuer \& Witsch, 270 pp. 
KESKIN Hakkı (2005) Deutschland als neue Heimat. Eine Bilanz der Integrationspolitik, Wiesbaden, Verlag für Sozialwissenschaften, 296 pp.

MARSHALL T. H. (2006) Yurttaşlık ve Toplumsal Sınıflar, in T.H. Marshall and Tom Bottomore (Eds), Yurttaşlık ve Toplumsal Sınıflar, Çev. Ayhan Kaya, İstanbul, İstanbul Bilgi Üniversitesi Yayınları, pp. 1-56. [Citoyenneté et Classes Sociales, traduction par Ayhan Kaya].

OBERNDÖRFER Dieter (2005) Die Rückkehr der Gastarbeiterpolitik, Blätter für Deutsche und internationale Politik, 6'05, pp. 725-734.

PROGRAMME FOR INTERNATIONAL STUDENT ASSESSMENT-PISA (2003), Where immigrant students succeed - A comparative review of performance and engagement in PISA 2003, OECD Paris, $222 \mathrm{p}$.

SCHIERUP Carl-Ulrik, Peo HANSEN and Stephen CASTLES (2006) Migration, Citizenship and the European Welfare State. A European Dilemma, New York, Oxford University Press, 328 p.

SCHÖNWÄLDER Karen (2004) Kleine Schritte, verpasste Gelegenheiten, neue Konflikte. Zuwanderungsgesetz und Migrationspolitik, Blätter für deutsche und internationale Politik, 10'04, pp. 1205-1214.

TC BERLİN BÜYÜKELÇiLİĞi Çalışma ve Sosyal Güvenlik Müşavirliği (2006), 2005 Yılı Faaliyet Raporu, Berlin, 65 p. [Rapport annuel d'activité 2005 de la Délégation au Travail et à la Sécurité Sociale de l'Ambassade de Turquie de Berlin].

TC ÇALIŞMA VE SOSYAL GÜVENLIK BAKANLiĞì Dış İlişkiler ve Yurtdışı İşçi Hizmetleri Genel Müdürlüğü (2002) 2000-2001 Raporu. Yurtdışındaki Vatandaşlarımıza İlışkin Gelişme Sayısal Bilgiler, Ankara, 542 p. [Rapport 2000-2001 de la Direction des Relations extérieures et des Services aux Travailleurs expatriés du ministère du travail et de la Sécurité Sociale].

ÜNVER O. Can (2006) Almanya'da Türk Kimliğinin Algılanma ve Tanımlanma Sorunları, Türk Yurdu, Nisan 2006, (224/26), pp.22-27 [Problèmes de perception et d'identité turques en Allemagne].

WEHLER Hans-Ulrich (2004) Die türkische Frage. Europas Bürger müssen entscheiden, in Claus Leggewie Hg., Die Türkei und Europa. Die Positionen, Frankfurt am Main, Suhrkamp, pp. 57-69.

ZAPTCIOĞLU Dilek (2006) Kein Zutritt für “Ausländer”. Die hermetische deutsche Leitkultur schließt Migranten aus, Internationale Politik Nr.3, März 2006, pp. 38-42.

\section{NOTES}

1. Alone in May 2006, 1,177 criminal acts by right-wing political scene were registered by the police in Germany. Among them were 88 acts of violence and 853 propaganda delicts. Deutscher Bundestag. 16.Wahlperiode. Drucksache 16/2195 vom 11.07.2206. Ausländerfeindliche und rechtsextremitische Ausschreitungen in der Bundesrepublik Deutschland im Mai 2006, Berlin.

2. The murder of a young woman, Hatun Sürücü, from South Eastern Turkey by her brothers in Berlin 2004 boosted a debate on the so-called customary murders, an issue of high brisance, also in some specific Eastern and South Eastern regions of Turkey, where individual gender problems are still perceived in a feudal manner. 


\section{ABSTRACTS}

Current integration discussion about the Turkish population in Germany is influenced by cultural essentialism. The political and social components of integration are by and large being neglected. The incorporation of migrants of Turkish origin into the society is praised as a superior target for the cohesion of the whole society, whilst cultural - national and religious - identities of Turkish migrants are comprehended as the real hurdles for the achievement of it. The scene is generally dominated by popular culturalist views of different authors, who blame the Turks of allegedly homogeneous Turkish group being incapable to be decent members of the society due to their cultural identity. In contrast to these mostly normative and emotional approaches to the issue, empirical evidence reveals a different picture : Shortcomings in the overall education system, delayed integration policies and structural national - and global - problems in the labour market seem to be the genuine reasons of failures. The migrant integration could be enhanced by creating equal opportunities for all members of the society in all societal levels. To challenge the existent and emerging future problems of migrant incorporation and diversity management, which should be free of emotional cultural essentialist views, the focus should be placed on the novel opportunities of inner and inter - state partnerships, using governance options in trans national social spaces, so to achieve a higher level of social equity and reconciliation within a pluralistic society, hence a society, which should consist of members with equal rights and duties.

Les débats en cours sur l'intégration en Allemagne: Approche culturaliste ou équité sociale ? À l'heure actuelle, les discussions sur la population turque en Allemagne sont sous l'influence d'un essentialisme culturel. Les composantes politiques et sociales de l'intégration sont largement négligées. L'intégration des migrants d'origine turque dans la société est valorisée en tant qu'objectif suprême de cohésion pour la société tout entière, alors que les identités culturelles - nationales et religieuses - des migrants turcs sont considérées comme les véritables obstacles à la mise en œuvre de cette cohésion. D'une façon générale, la scène est dominée par les vues culturalistes fréquemment émises par certains auteurs, qui reprochent aux Turcs supposés appartenir à un groupe homogène d'être incapables de devenir des membres convenables de la société, en raison de leur identité culturelle. À l'opposé de ces approches du problème, essentiellement normatives et émotionnelles, des données empiriques font apparaître une image différente : les insuffisances du système éducatif en général, les retards dans les politiques d'intégration, ainsi que des problèmes structurels nationaux - et généraux - sur le marché du travail semblent être les vraies raisons de ces échecs. L'intégration des immigrants pourrait être améliorée par la création d'une égalité des chances pour tous les membres de la société, à tous les niveaux. Le traitement des problèmes, actuels et émergents pour l'avenir, de l'intégration des immigrants et celui de la diversité, devraient être dépourvus de visions culturelles émotionnellement essentialistes afin de se concentrer sur les nouvelles opportunités de partenariats dans les Länder et entre Länder, en se servant des principes de gouvernance des espaces sociaux transnationaux, afin de parvenir à un degré supérieur d'équité sociale et de réconciliation dans une société pluraliste, c'est-à-dire une société qui serait composée de membres ayant des droits et devoirs égaux.

Debates actuales sobre la integración en Alemania: ¿Perspectiva culturalista o equidad social? Hoy en día, el "esencialismo" cultural influye en los debates sobre la población turca en Alemania, desestimando ampliamente los componentes políticos y sociales de la integración. La integración de los emigrantes de origen turco en la sociedad es valorizada en calidad de objetivo supremo de cohesión de la sociedad en su totalidad. Las identidades culturales (nacionales y 
religiosas) de los inmigrantes turcos son consideradas, por su parte, como los verdaderos obstáculos para el logro de dicha cohesión. De manera general, la escena está dominada por los puntos de vista culturalistas de ciertos autores que reprochan a los turcos, que se supone pertenecen a un grupo homogéneo, de ser incapaces, a causa de su identidad cultural, de convertirse en miembros convenientes de la sociedad. En oposición a estas perspectivas del problema, esencialmente normativas y emocionales, datos empíricos revelan una imagen diferente: las verdaderas razones de estos fracasos parecen ser las insuficiencias del sistema educativo en general, los retrasos en las políticas de integración así como los problemas estructurales nacionales (y generales) del mercado laboral. La integración de los inmigrantes podría ser mejorada a través de la creación de una igualdad de oportunidades para todos los miembros de la sociedad y a todos los niveles. El tratamiento de los problemas (actuales y emergentes) de integración de los inmigrantes y de diversidad debería ser despojado de visiones culturales emocionalmente esencialitas para concentrarse en nuevas oportunidades de partenariado dentro y entre Länders. Para ello, se podría recurrir a principios de gobernanza de espacios sociales transnacionales con el objetivo de alcanzar un grado superior de equidad social y de reconciliación en una sociedad pluralista; es decir, una sociedad que seria compuesta por miembros que gozan de iguales derechos y deberes.

INDEX

Geographical index: Allemagne

Mots-clés: égalité des chances, intégration

\section{AUTHOR}

\section{O. CAN ÜNVER}

Docteur, membre du Conseil scientifique du Centre de recherche sur les Migrations, Université de Koç, Istanbul. 